\title{
PALABRAS NÓMADAS: LOS NUEVOS CENTROS DE LA PERIFERIA
}

Nomadic words: The new centers in the periphery

Fernando Ainsa*

Resumen

Este artículo plantea que, en la actualidad, se ha producido una pérdida del "mapa" de los referentes identitarios de la literatura latinoamericana que ha ido borrando fronteras nacionales, lo que supone la ruptura de un modelo de escritor y una recomposición de su papel en la sociedad. Por lo mismo, el autor propone que el estudio de los "territorios flotantes" de esta nueva cartografía literaria no es fácil de situar en el "organigrama" de la crítica clásica de la literatura latinoamericana, acostumbrada a dividirla por períodos y países, sin considerar esta "transterritorialidad" que presenta la narrativa actual.

Palabras clave: Narrativa hispanoamericana, exilio, globalización y periferia.

Abstract

This article argues that, at present, there has been a loss of the "map" of identity references of Latin American literatura, which has been blurred national borders, resulting in the breakdown of a model of a writer and a restructuring of his role in society. For this reason, the author proposes that the study of the "floating territories" of this new literary cartography is not easy to place on the "flowchart" of the classical tradition of Latin American literature, which uis accustomed to divide by periods and countries, regardless of the "trans-territoriality" that current narrative presents.

Key words: Hispanic Narrative, exile, globalization and periphery.

Desde el rincón de Normandía, donde vivió gran parte de su vida, Gustave Flaubert aseguraba: "No soy más francés que chino" y sostenía que "apenas entendía lo que significaba patria", anunciando que iba a hacer su equipaje para irse bien lejos, "a un país donde no escuche la lengua, lejos de todo lo que me rodea, de todo lo que me oprime". Sentado junto al fuego soñaba "con viajes, con recorridas sin fin a través del mundo", aunque "más triste después", volvía de nuevo a su trabajo (Flaubert, 1947:56).

Unos años más tarde, James Joyce exclamaría en Trieste: "iQue mi patria muera en mí!", para afrontar, lejos de su Dublin natal, la intemperie de otras tierras y otros idiomas. Un James Joyce que había hecho decir años antes a Stephen Dedalus, en Retrato de un artista adolescente (1916): "No quiero servir más a aquello en lo que ya no creo, llámese mi hogar, mi patria o mi iglesia; trataré de expresarme, según un modo de vida y una forma de arte, tan libremente como pueda y lo más integralmente posible, usando para defenderme las solas armas que me permito utilizar: el silencio, el exilio y la 


\section{Fernando Ainsa}

astucia" (Joyce, 1956:207). Con palabras similares, el polaco Gombrowicz resumía: "Cuando escribo, no soy ni chino ni polaco".

O como confiesa ahora Enrique Vila-Matas: "De un tiempo a esta parte, yo quiero ser extranjero siempre", un escritor que decidió aplicarse a sí mismo la ley de extranjería para dejar de ser un escritor español y habitar un "territorio sin aduanas". Se trata de "viajar, perder países" y sentirse en Barcelona, su ciudad natal, como "un pasajero en tránsito hacia ciudades lejanas" (2007:21); se trata de buscar un lugar donde nadie lo conozca y "llevar a cabo la experiencia de volver a empezar, pero con el equipaje de toda la experiencia adquirida durante estos años" (2007:322). En un extremo aún más radical, Cioran exclama "lo extranjero se había vuelto mi Dios" (1986:162) convirtiendo su exilio en una apasionante aventura fundacional del desarraigo y de esa capacidad de sentirse en "casa" en cualquier cultura. Tal vez por ello, el poeta portugués Jorge de Sena sospechaba que: "Eu sou eu mesmo a minha patria", después de haber afirmado en forma provocadora que "Coleccionarei nacionalidades como camisas se despem".

Detrás de estas boutades y de estas provocaciones, puede adivinarse el anhelo de fundar un territorio nuevo e independiente, lejos del solar nativo, que caracteriza buena parte de la literatura contemporánea. En esos territorios exteriores - donde se han refugiado quienes han hecho realmente sus maletas - se consagran el desarraigo, el exilio voluntario o forzoso, esa condición nomádica del artista contemporáneo que marca la narrativa del siglo XX, tendencia que no hace sino agudizarse en este nuevo milenio y que tiene sus particulares características en América Latina, donde la literatura transfronteriza multiplica escenarios y puntos de vista desasida de la noción unívoca de identidad y de patria.

"La sensación es de desprejuicio territorial" — concreta el argentino Andrés Neuman - un abandono del propósito de "encarnar determinados esencialismos nacionales y políticos" para reformularlos apostando a una literatura que pueda estar adscrita a cualquier espacio, metonimia del mundo que no se siente obligada a retratar la realidad de acuerdo a los tópicos que los lectores esperan de ella. "El chovinismo en la literatura es un cáncer extirpable" - cree por su parte el peruano Diego Tréllez, radicado en Nueva York y autor de Hudson el redentor y otros relatos edificantes sobre el fracaso (2001) - , ya que "lo nacional tiende a ser un concepto desfasado para analizar nuestras correspondencias" (2008:6). Lejos del compromiso y de la misión del escritor en boga, hará unas décadas, ha compilado una antología desacralizadora de título significativo, El futuro no es nuestro. Narradores de Latinoamérica (2008).

Con la pérdida del "mapa" de los referentes identitarios, la literatura latinoamericana ha ido borrando fronteras nacionales, lo que supone la ruptura 
de un modelo de escritor y una recomposición de su papel en la sociedad. Ya no hay necesidad de pedirle cuentas por su aporte a la literatura nacional, esa imposición de representar a un país a la que sentía obligado hasta no hace mucho todo escritor y que parodiara Julio Cortázar en 62 Modelo para armar, cuando sus engominados personajes intentan asumir un "destino argentino" en Europa. Representar un país, como lo hacen los ridículos porteños paseando por Londres y París con "trajes a rayas y entallados" y peinados de un modo penoso (1968:90) llega a conformar una caricatura existencial de la auténtica dificultad de tener una identidad fijada. Esos trajes solemnes son un auténtico disfraz con el cual se quiere transmitir una seriedad y aplomo que íntimamente no se posee, "esa especie de padre argentino de sienes plateadas y trajes bien cortados que inspiran confianza" (1968:120). Por algo Cortázar inicia Rayuela con la significativa cita de Jacques Vaché: "Rien ne vous tue un homme comme d' etre obligé de représenter un pays".

Existe ahora, por el contrario, una "geografía alternativa de la pertenencia", lealtades múltiples que se generan a través de la pluralidad y de las "pulsiones de otro lugar" que asaetan al escritor, la trasgresión y la mezcla de códigos y la exaltación del descentramiento y de la marginalidad, como analizaremos. Francisca Noguerol en Narrar sin fronteras, sostiene que

Vivimos un momento en que la búsqueda de identidad ha sido relegada a favor de la diversidad: como consecuencia, la creación literaria se revela ajena al prurito nacionalista a partir del cual se la analizó desde la época de la Independencia, aún vigente en múltiples foros académicos y que rechaza la literatura universalista como parte del patrimonio cultural del subcontinente (2008:20).

Sin embargo, el estudio de los "territorios flotantes" de esta nueva cartografía no es fácil de situar en el "organigrama" de la crítica clásica. Parafraseando la afirmación de que "nada molesta tanto a un burócrata como la libertad de los hombres errantes" se podría decir que nada molesta más a un especialista de literatura latinoamericana, acostumbrado a dividirla por períodos y países, que la "transterritorialidad" de la narrativa actual. Sus preguntas son: ¿Dónde clasificarla?; ¿Bajo qué área regional o nacional estudiarla?; ¿A qué Departamento universitario adscribirla?

\section{LAS FIGURAS DE AFUERA}

Nos proponemos cuestionar estas interrogantes. Para ello hay que partir de la idea de "no pertenencia a un lugar", de una realidad hecha de fronteras esfuminadas, viajes de ida y vuelta, "vagabundeos iniciáticos" (Maffesoli, 2005) "cultura del camino", "callejeo" impenitente, impulsos de vida errante, nomadismo asumido como destino, aspiraciones a "estar en otro lugar" y de "salir de sí mismo" que favorecen también los mundos virtuales del espacio 


\section{Fernando Ainsa}

cibernético, aprendizajes en la otredad y — ¿Por qué no? - secreta nostalgia por el mundo perdido de los orígenes, en que se reconoce buena parte de la narrativa contemporánea. Lejos de reivindicaciones patrióticas o identitarias, el escritor, homo viator por excelencia, puede preguntarse - como hace el colombiano Eduardo García Aguilar- “Dónde queda el extranjero?” tras tantas fusiones y mestizajes, viajes, ausencias y retornos, “ ¿En la patria abandonada o en las patrias adquiridas a fuerza del éxodo? ¿Quién es más extranjero: el nativo que retorna a deambular por sus parajes nativos o el forastero que agota el asfalto de nuevas y luminosas metrópolis del Viejo y del Nuevo Mundo? (2006:60).

En resumen, como afirma otro colombiano, Juan Gabriel Vásquez: "la literatura latinoamericana actual es hoy como la naturaleza según Pascal: una esfera cuyo centro está en todas partes y su circunferencia en ninguna" (2007:19). En todo caso, se trata de evitar ser latinoamericano como se espera que se debe ser para satisfacer el imaginario europeo: lejos de los tópicos y clichés con que siempre se lo ha caracterizado. En su esfuerzo por destruir esos tópicos, Vásquez recorre los espacios y lugares de París por donde han pasado Joyce, Scott Fitzgerald, Hemingway o Gertrude Stein para empaparse literal y literariamente de su atmósfera. Desde las Ardenas escribe Los amantes de Todos los Santos (2008) que define como "libro europeo de un escritor colombiano", relatos que se desarrollan en Bélgica y Francia, donde vive, porque escribe "sobre lo que conoce". (Colombia, su patria de origen, es "una tierra desconocida llena de misterio"). Por ello, reivindica el derecho a sentirse heredero y trabajar con la literatura universal, ya que "nadie tiene que justificarse, como les tocó a Borges o a Cortázar, por contar historias europeas o indias o norteamericanas o con personajes de esas regiones. Nuestra tradición es toda la literatura" (2008:6).

Estas "figuras de afuera" (White 1997:15) que amplían la idea política del exilio y la reductora imagen botánica del enraizamiento y el desarraigo, se inscriben en la condición que George Steiner definiera como extraterritorialidad y la pluralidad lingüística que la acompaña, "carencia de hogar" que caracteriza la obra de grandes escritores como Nabokov, Borges y Beckett (1973:10) y que reivindican ahora con orgullo los escritores latinoamericanos que han hecho del "afuera" su patria literaria. ${ }^{1}$

\footnotetext{
${ }^{1}$ Basta pensar en quienes viven por decisión propia o forzados por las circunstancias en Madrid, Barcelona, París, Estocolmo, Berlín, Nueva York o Los Angeles, pero también en Ciudad de México, como ha decidido Fernando Vallejo, aunque sea para despotricar contra Colombia su patria de origen, en esa ambigua relación de amor-odio que caracteriza la obra de muchos escritores que "han decidido hacer sus maletas". Arturo Arias lo confiesa con tono abatido: "Uno se cansa de amar a este maldito país aun cuando se programe para odiarlo.
} 
Palabras nómadas: los nuevos centros de la periferia

\section{EL FUGITIVO CULTURAL}

Todo indica que los procesos de mundialización en que estamos inmersos, las facilidades para viajar y comunicarse, las herramientas de Internet, gracias a las cuales forjamos afinidades electivas en desmedro de las territoriales o étnicas, agudizan esta condición errante del escritor. Numerosos intelectuales y artistas exploran ahora la diversidad material y cultural de un mundo del que han eliminado esas fronteras, aunque políticamente sigan existiendo, al incorporarse a otras colectividades para intercambiar ideas y experiencias estéticas. Ello permite - como propone el pintor chileno Eugenio Dittborn - superar "los sacrosantos emblemas de identidad, verdaderos distintivos estereotipados de nosotros como víctimas exóticas" y forjar una mirada "múltiple, politeísta y módica", gracias a la cual se puede abrir el proceso de una interacción crítica con la tradición entendida como memoria de un pasado histórico que debe ser revisitado en permanencia (1993:211). Se trata de romper los muros que se levantan frente a la alteridad en un entorno cada vez más ambivalente y "mestizo" que reclama superar el distingo entre dentro y fuera, nacional e internacional, nosotros y los otros, con una visión capaz de expresar la plasticidad cultural y el carácter dialógico del mundo contemporáneo. ${ }^{2}$

Con la globalización de los mercados y los progresos de los medios de comunicación, individuos y pueblos viven en coexistencia permanente, para la cual no hay fronteras ni una base territorial única. Este proceso ha coincidido con la generalización de los medios de comunicación y con el acelerado desarrollo de Internet. Gracias a ellos, el hombre vive realmente en "la aldea mundial" de la que habló con tono premonitorio Mac Luhan y repetía Octavio Paz a escala latinoamericana cuando afirmaba que "por primera vez en nuestra historia, somos contemporáneos de todos los hombres" (1982:174).

Una cultura de difusión instantánea y simultánea refleja el evento, el acontecimiento, el momento vivido fuera de los referentes espaciales y temporales. Allí lo contingente es contiguo, aunque el día a día no deje de seguir articulando la continuidad histórica y esa sensación ineludible de vivir la noticia en "vivo y en directo", como se dice en la jerga televisiva. Este vivir al día a nivel del mundo ha llevado a que Paul Nizan, un nómada cultural que

Dependiendo de que lo sueñe o viva en él es un desvencijado paraíso o una embotada prisión armada con espinas de rosales" (2002:11).

${ }^{2}$ Es interesante destacar la renovada actualidad del "cosmopolitismo ilustrado" que han puesto de relieve obras como La mirada cosmopolita o la guerra es la paz de Ulrich Beck (Barcelona, Paidós, 2005:264) y la Reivindicación de la Ilustración. Hacia una política de compromiso radical de Stephen Bronner (Pamplona, Laetoli, 2007:240). 


\section{Fernando Ainsa}

ha residido en Italia, Francia y España, afirme: "Si estoy inmerso en el presente estoy vivo. Vivo en este mundo. Pertenezco a mi tiempo. Soy un contemporáneo". Por ello, José Luis Abellán ha propuesto que junto a la reflexión sobre la globalidad se profundice la idea de "simultaneidad" (1994).

Esta condición de lo actual y lo inmediato como vivencia está estimulada en forma provocativa por circuitos y redes interculturales de todo tipo. En la intimidad de la pantalla de ordenadores y gracias a los webb-on line, los chats y blogs de Internet, se desarrolla una cultura del ciberespacio, cuyo territorio de relaciones es interactivo y fundacional de verdaderas comunidades virtuales transnacionales, donde en una especie de "club mundial" de la realidad virtual se vive tanto en la realidad-real como en la ilusión de una nueva dimensión de la centralidad creativa. Verdaderas "redes de conversación" se constituyen en forma horizontal, desplazando el orden jerárquico verticalizado de antaño, horizontalidad que ha generado una arquitectura interactiva del saber más compleja que en el pasado y ajena al modelo tradicional centro-periferia.

Se exalta así la "condición nomádica" y la figura del "fugitivo cultural" como componentes de una identidad que ya no es unívoca - territorio y lengua y menos aún étnica- sino múltiple, capaz de esgrimir, según qué circunstancia o conveniencia, uno u otro pasaporte. Se recuerda el principio heideggeriano de que "sin desorientación y sin pérdida, sin errar por senderos que se extravían en el bosque, no hay llamada, no es posible escuchar la auténtica palabra del ser" (Heidegger, 2001:68).

"La vida errante, el nomadismo, está inscrita en la estructura misma de la naturaleza humana ya sea ésta individual o social" (Maffesoli, 2005), fascinación y repulsión por el cambio reflejado en la literatura desde tiempos inmemoriales en viajes iniciáticos, en una imperiosa necesidad de fuga, en la reactivación vital de la aventura en un espacio desconocido. Desde el Ramayana y su mono volante, el infatigable Ulises de La Odisea, las aventuras y amores de Eneas en La Eneida, el éxodo de un pueblo en la Biblia, la epopeya de las caravanas de Las Mil y una noche, las errancias de Don Quijote, el viaje iniciático del Cándido de Voltaire, los Naufragios de Álvar Núñez Cabeza de Vaca, el mito del caballero andante, sean cuales fueran las figuras contemporáneas que pudieran encarnarlo, continúa presente en el imaginario colectivo y se refleja en el impulso del pionero, en la fascinación que ejerce lo extraño, en el afán secreto de fundar en otro mundo, una patria alternativa, tal vez ilusoria y en la tentación de la escritura errante que Julio Ramón Ribeyro reivindica con cautela y cierto escepticismo en sus Prosas apátridas

Durante diez años viví emancipado del sentido de la propiedad, de la profesión, de la familia, del domicilio y viajé a oír el mundo con una 
maleta llena de libros, una máquina de escribir y un tocadiscos portátil y cedí a sortilegios tan antiguos como la mujer, el hogar, el trabajo, los bienes. Es así que eché raíces, elegí un lugar, lo ocupé y empecé a poblarlo de objetos y de presencias (1975:144).

La moraleja descubre que en la "vida acumulativa" de la condición sedentaria y en su desgaste inherente se anuncia el "umbral de la muerte". Por el contrario, los encuentros, perspectivas mutuas e intercambiadas, cuando no intercambiables, intersecciones y separaciones motivadas que procuran sentimientos tan dispares como la fuga de sí mismo y la necesidad del contacto y el encuentro en el otro, son temas ensalzados por escritores que, muchas veces, llevan en sí esa ambivalente condición. Ser fugitivo en una lengua extranjera, dicen unos, perderse de nuestra propia lengua en tierras extrañas, proponen otros. En todo caso, vivir siendo siempre un extranjero, porque se está perdido en la propia tierra. Con una similar perspectiva, Eduardo Mallea ya había sostenido en Historia de una pasión argentina que "no se va a ninguna parte sin desterrarse", porque "el camino de la creación es el camino del destierro" (1939:61) ya que hay momentos de rechazo y otros de aceptación, horas en que debe optarse entre quedarse atado a la "ficción circunstancial" o desterrarse. Vivir fuera del "lugar en que se ha nacido" es un destino en sí; integración en redes que desconocen los límites nacionales y culturales y donde se esfuminan las fronteras, para estar "en casa" en todas partes, como soñaba Novalis.

Hay ejemplos que pueden parecer extremos. Propiciando un divorcio creciente entre la producción ficcional latinoamericana, una buena parte de la narrativa se expande en un movimiento centrífugo de vocación universal y circula, sin necesidad de señalar su patria de origen, con temas y estilos de un deliberado cosmopolitismo. Incluso, como es el caso del guatemalteco Rodrigo Rey Sosa y del mexicano Ignacio Padilla (Amphitryon, 2000) haciendo gala de su versatilidad y de su voluntad de "internacionalismo temático", ajeno a todo referente nacional. Jorge Volpi, aunque afirma razonablemente que "las respuestas absolutas son siempre mentiras", revisita la historia contemporánea europea del siglo XX en textos como En busca de Kingsor (1999), El fin de la locura (2003) y No será la tierra (2006). Volpi lo hace con la mirada desencantada de quien sabe lo que ocurrió con posterioridad al tiempo de la narración, al margen de todo referente mexicano. Con tono falsamente sorprendido confiesa

A fines de los noventa, mientras preparaba mi doctorado en Salamanca, descubrí que era latinoamericano. Durante los 30 años que viví en México jamás reparé en esa condición: sólo el contraste con mis anfitriones españoles, más directos y claros que mis compañeros costarricenses, venezolanos y colombianos, me hizo sentir parte de la 


\section{Fernando Ainsa}

comunidad bolivariana. La identidad, comprendí entonces, es mutable y se construye en perpetuo contraste con los otros (Volpi, 2008:36).

Por su parte, el chileno Roberto Bolaño, habiendo vivido en varios países y con un largo período en Barcelona, manejó una polivalencia estilística y temática que le permitió escribir libros en "colaboración" con Antoni García — como Consejos de un discípulo de Morrison a un fanático de Joyce (1984) - e "inventar" una literatura inexistente, como en los juegos de filiación borgiana en La literatura nazi en América (1996), donde propone una especie de manual con sus reseñas de libros y biografías de escritores imaginarios. ${ }^{3}$

\section{EN EL CENTRO DE LA NADA}

Para asumir el extremo de este desarraigo y convertir la fuga y la carencia de patria en modelo de vida bajo el lema de que "un encuentro sólo alcanza su plenitud en la espera", el ecuatoriano Javier Vásconez en El viajero de Praga (1996) propone un protagonista checo, el médico Josef Kronz. Sospechando que está vigilado en su ciudad natal, descrita con evidentes alusiones literarias a Jan Neruda y a Kafka, aprovecha un congreso en Barcelona para escaparse y vivir en una ambigua incertidumbre su condición de "extranjero profesional" instalado en la movilidad y en la periferia de su propio mundo, hasta que decide irse a un lejano país sudamericano. Tras las vagas descripciones de esa tierra a la que accede sin la energía necesaria de un inmigrante, se adivina la melancolía andina, probablemente del Ecuador. "De todos los lugares en el mundo ¿Por qué había elegido éste precisamente?”, se interroga el narrador para responder con otra pregunta: "Es posible que Kronz haya venido al país más apartado del mundo, incluso al más olvidado, creyendo que iba a realizar una labor extraordinaria (...) ¿O quizá fue un acto suicida el haber hecho el viaje hasta aquí, pues a lo mejor venía huyendo de algo", para dejarse "anestesiar por la lluvia a fin de afrontar tan devastadora mediocridad" (1996:66). ${ }^{4}$

\footnotetext{
${ }^{3}$ Esta misma volubilidad le ha permitido novelizar la biografía, entre real e imaginaria, de un impostor navegando en el turbulento período del Golpe de Estado en Chile en Estrella distante (1996); abordar una especie de novela negra en Los detectives salvajes (1998) y, manejando hábilmente una compleja polifonía de voces, narrar una trama española de corrupción a escala municipal, salpicada de "pícaros" latinoamericanos en La pista de hielo (1998), para finalmente aterrizar en la zona fronteriza de Ciudad Juárez en el despliegue estilístico de 2666 (2004).

${ }^{4}$ Identificado como "el hombre de la gabardina", atuendo llamativo en esas latitudes, no logra tampoco integrarse en esa ciudad remota. Abrumado por el peso de la traición de haber abandonado Praga "sin un propósito determinado" se dice que siempre será un extraño, dondequiera que vaya. “Es que tendría siempre la sensación de estar en la orilla equivocada del río?” (1996:87) se repite. En todo caso, en el trópico se vive con la sensación de llegar a
} 
Los viajes de Kronz empiezan en la mente para dirigirse a puntos lejanos donde, quizás, "no debiera estar" (1996:150) o donde su conciencia le dice que ya ha estado antes, aun cuando no pueda precisar en qué momento y de dónde le llega esa sensación. A veces sospecha que es de un libro ilustrado de un viajero inquieto como Humboldt, leído en forma enfebrecida en las frías madrugadas de Praga. Los luminosos paisajes andinos, la tristeza de sus gentes, esa ciudad que se le ofrece como un refugio, son ecos de otras imágenes que reviven en su trabajo como médico en un viejo hospital "a la deriva" cuando es invadido por una epidemia de cólera. Aun en esa circunstancia extrema vive con la sensación de que le da igual estar allí o en cualquier otro sitio. Según le escribe un lejano amigo de Praga sigue siendo "un misterio el que hayas decidido quedarte por allá, en la mitad del mundo, precisamente tú, que nunca creíste en el centro de nada" (1996:298).

La obra de Leonardo Valencia, otro ecuatoriano, se inscribe, también, en este deliberado cosmopolitismo sin asidero nacional. En El desterrado (2000) narra la historia de tres generaciones de los Dalbono, una familia romana; en El libro flotante de Caytran Dolphin (2006) aborda el tema de la emigración y sus implicaciones sociales y culturales en su personaje Iván Romano, judío italiano, emigrando a Guayaquil. Novela de intensas referencias literarias, no hace sino comprobar la imposibilidad del arraigo americano cuando se es portador de una compleja historia europea. ${ }^{5}$

\section{LA VIDA ERRANTE}

El uruguayo Carlos Liscano demuestra que la trashumancia, la inquietud del viajero, exilado o emigrante, no puede procurar ningún alivio al que busca un cambio de domicilio y de país. "Uno es así, aún no ha llegado y ya quiere marcharse, como si las cosas fueran a mejorar porque uno cambie de lugar" se dice al inicio de El camino a Itaca (1994:5), una novela-saga sobre las aventuras tan patéticas como humorísticas del "meteco" Vladimir, entre Estocolmo y Barcelona y con alusiones a un país sudamericano (Uruguay) que estuvo sometido a una dictadura. Con un cierto cinismo protector, sin mucha autoestima,

todo con retraso, "siempre a ciegas y con retraso" y donde nunca se sabe nada con certeza. Kronz sólo regresa a Praga en reiterados sueños para pensar en forma paradójica, mientras pasea a orillas del Moldava: "Si yo hubiera sabido que iba a volver, tal vez no habría venido" (1996:121). En sus sueños tiene la impresión de no haber salido nunca de Praga, aunque lo abruma en forma opresiva el hecho de "haber vuelto voluntariamente a esa ciudad" (1996:127).

${ }^{5} \mathrm{Al}$ mismo tiempo, Valencia ha denunciado lo que llama el "síndrome de Falcón" de los escritores ecuatorianos: cargar sobre sus espaldas una agenda de compromiso con su país, con una finalidad reivindicativa de urgencias identitarias y nacionalismo patriotero, de representaciones reductoras de mitos arcaicos. No respetar esas reglas no escritas, pero tácitamente acatadas, supone la acusación de pretensión cosmopolita, desvío burgués que, calificado de "perversión nacionalista", lleva a la autocensura. 


\section{Fernando Ainsa}

Vladimir, apenas llega a un lugar siente la necesidad de irse a otro: "Vale decir, estaba en lo mío, movimiento perpetuo, siempre tratando de ver qué hay del otro lado de la montaña. Ya sentía cosquillas bajo los pies" (1994:22).

Pese a que comprueba que siempre "uno viaja consigo mismo a todas partes, es el que es, en Siberia o en la Luna. Esto no tiene arreglo. Después que se nace nada tiene arreglo, uno ya es el que va a ser, mierda o cielo para toda la vida" (1994:18), no deja de evadirse a un espacio onírico, una cabaña al modo de la que imagina en Alaska Eladio Linacero, en el El pozo de Juan Carlos Onetti, aunque deba convivir lidiando con la picardía de otros inmigrantes indocumentados, jerarquizados para explotarse mutuamente y se conforme con ser "extranjero en todas partes" y a ejercer los más bajos menesteres para sobrevivir. ${ }^{6}$

Estos viajeros pueden ser personajes a quienes el azar sumerge en una inesperada aventura, como narra con tono irónico y divertido el colombiano Santiago Gamboa en Los impostores (2002). En la novela, Suárez Salcedo - un colombiano de 42 años que reside en París desde hace casi veinte y trabaja en Radio France International- viaja a China en misión periodística; el sinólogo alemán Gisbert Klauss, profesor de cultura china en la Universidad de Hamburgo lo hace tras sus investigaciones filológicas; el peruano Nelson Chouchén Otálora, nieto de un inmigrante chino, recalado en la Universidad norteamericana de Austin y viviendo sin la nostalgia del "malhadado país", busca datos biográficos para escribir una novela sobre la inmigración china en Perú: los tres coinciden en Pekín. El viaje inicialmente con propósitos diferentes de cada uno de ellos se va entrelazando alrededor de una rocambolesca búsqueda de un manuscrito perdido de una secta católica china sumida en la clandestinidad. El manuscrito termina siendo falsificado, merced a minuciosas copias y los protagonistas terminarán convertidos en tres impostores, dueños — cada uno de ellos- de una verdad diferente.

El exotismo está también presente en el humor de Son cuentos chinos (1983) y De Pe a Pa (o de Pekín a París) (1986) de la argentina Luisa Futoransky. "Cancelo la nostalgia de un plumazo", empieza diciendo en su suerte

\footnotetext{
${ }^{6}$ Lavaplatos, repartidor de periódicos, envasador de mejunjes en una fábrica de "cosméticos" de mala muerte, regentada por un compatriota explotador. Excluido del sistema, Vladimir encuentra una lógica en la rigidez administrativa de un hospital psiquiátrico. Allí comprueba que "yo no sé si cuando uno está loco dice de verdad lo que siente o también hace como todo el mundo, se inventa mentiras para sostener alguna forma de vida social" (1994:93). En todo caso, viviendo bajo el orden reglamentario sospecha que es posible una forma de la felicidad. "La felicidad no existe, pero uno puede inventársela — se dice, aunque no esté muy convencidoNo, no, la felicidad era la búsqueda, había que seguir, arriesgar. La felicidad no estaba en resignarse, en no buscar más, en encontrar una rutina posible y a ella atenerse" (1994:270). La alternativa no puede ser más antinómica: seguir buscando o resignarse a una rutina programada.
} 
de desgarradas y divertidas memorias de su estadía en China, trabajando en el Departamento Internacional de Radio Pekín, para precisar que "en el exilio no se velan las armas sino el cartero. Siempre, siempre, desde hace veinte años la esperanza en el cartero o el teléfono con el mensaje milagroso que cambiará el curso de la vida" (1983:15). En Pekín se siente solo nostalgia de "por favor un poco de verde" (1983:42) y mucha opresión de un sistema que vigila y controla todos sus movimientos. "Existen leyes férreas para todo: para la forma, color, contenido y orden de los platos, los saludos, hasta para la redacción de cartas y noticias; y contra ella no hay quién pueda" (1983:184), comprueba apesadumbrada. Sin embargo, sabe que nadie la recuerda en Buenos Aires porque "ellos me abandonaron mucho más de lo que yo les abandoné" (1983:199). En resumen, "la vida es mucho más turbia, menos clara que las novelas" (1983:185).

De todos modos, vivir en lugares tan lejanos y diferentes deja marcas indelebles. En De Pe a Pa (o de Pekín a París), Futoransky comprueba que por haber vivido en China, cualquier noticia proveniente de allí, aún transcurridos años desde su regreso, "le altera el pulso", porque "la tiene demasiado cerca, en carne viva" (1986:11). De todos modos, hay otras variantes: la negación de esa otredad por saturación o por alergia a todo lo que traiga recuerdos de esa estadía en Pekín, pero también la de recomenzar en otro escenario esa búsqueda imposible de la "casa" para fijar un centro de sí misma. En París es "durísimo". El hogar es un "lugarejo más o menos sórdido; una pieza generalmente poco soleada, a veces sin baño, otras sin cocina; otras sin baño, cocina ni ascensor" (1986:35). En la novela, Laura Kaplansky vive su extrañamiento —ese "modo fundamental de ser en el mundo", opuesto al culto del arraigo, al decir de Heidegger - de un modo entre complacido y resignado. En una nota final, a pie de página, Futoransky confiesa haberla creado para tratar de explicar que "es ser poeta suelto por el mundo, con sus particulares agravantes; mujer mayor, pobre, judía, argentina y sola" (1986:123-124).

\section{EL PRESTIGIO DEGRADADO DE PARÍS}

"París es una fiesta", escribió Hemingway en los alegres y despreocupados años veinte, cuando los integrantes de la "generación perdida" recibían su bautizo iniciático en el Barrio Latino de la Rive gauche. También lo era para los escritores latinoamericanos encandilados por los resplandores de la "Ciudad Luz" y descubriendo en la fórmula del surrealismo, a lo largo de noches de bohemia y delirio, la clave para desentrañar el "realismo mágico" y lo "real maravilloso" de sus propios y recónditos mundos. Miguel Angel Asturias, Jorge Luis Borges, Alfonso Reyes, César Vallejo y luego Alejo Carpentier y Octavio Paz lo reconocieron en sus obras, vagando alegremente en las madrugadas tras las huellas de la "Nadja" de André Breton. 


\section{Fernando Ainsa}

Trasplantados y "rastacueros", "señoritos" y escritores de variopinta condición, algunos tildados de afrancesados, otros copiando modas literarias o vestimentas, los habían precedido a fines del siglo XIX y en los albores del XX, haciendo de París una cita inevitable de su formación. La Generación argentina y chilena del 80 lo practicó y testimonió en obras representativas: Los trasplantados de Alberto Blest Gana y Criollos en París de Joaquín Edwards Bello, se prolongarían en los "niños bien porteños" de Música sentimental y Sin rumbo de Eugenio Cambaceres y, unos años después, en Raucho de Ricardo Güiraldes y en Ifigenia de Teresa de la Parra.

Los tópicos más conocidos de París — de los que amores ligeros y aventuras sentimentales, "cabarets" y el famoso Moulin Rouge inmortalizado por Toulouse Lautrec formarían parte - se forjaron al socaire de esos años y se reflejaron en las páginas de poemas, cuentos, novelas y memorias. Algunos poetas, en el colmo del mimetismo, llegarían a escribir directamente en francés. Otros, como César Vallejo, se dirían con tono melancólico: "Me moriré en París con aguacero/ un día del cual tengo ya el recuerdo".

Pretexto literario siempre, París no ha sido, sin embargo, el mismo en todas las épocas. De la "Meca" a la que había que acudir una vez en la vida para ser reconocido como escritor respetable en el solar nativo, se pasó en los años setenta al París "tierra de asilo" y refugio para los perseguidos de las dictaduras que asolaron el continente, especialmente en el Cono Sur. Estos escritores ya no vivían en las alegres buhardillas del Barrio latino, sino en arrondissements empobrecidos y banlieues alejadas de los centros culturales prestigiosos y desde allí fueron edificando una nueva "poética" urbana hecha de pluralidad y diferencia. Así, París empezó a ser como Londres o Nueva York: el apasionante laberinto de "galerías secretas" que construye pasajes subterráneos entre ciudades de hemisferios diferentes, pero también entre "comunidades" diversas que coexisten entre sus muros. Cortázar, fundador de los "modelos para armar" de un mapa cuyo puzzle deben descifrar los lectores, inaugura una ciudad a la medida de un juego como Rayuela.

Los escritores exiliados buscaron menos un reconocimiento local que una distancia y un respiro para evocar, desde lejos, los fragmentos de sus respectivos países desgarrados y recomponer, con nuevos ingredientes, una identidad dividida ambiguamente entre las lealtades múltiples que se iban generando. En este contexto, con la compleja especificidad de una revolución que marcó a una generación de latinoamericanos, se fueron injertando las voces que llegaban desde Cuba, donde más allá de crecientes disidencias, el cordón umbilical se niega a romperse.

A partir de los años noventa, cuando muchos exiliados acuciados por la nostalgia deciden retornar a sus países, donde democracias cojitrancas no dejan de ofrecer una cierta libertad, vivir en París volvió a ser una opción personal, aunque 
muchas veces acotada por prosaicas necesidades económicas. Este es el escenario actual, lejos de los tópicos, incluso de los languidecientes del existencialismo o de los más recientes del estructuralismo y los seguidores devotos de Lacan o de Foucault.

París, sin embargo, sigue siendo escenario por excelencia, aunque ahora personajes y autores trashumantes se muevan con desenfado en un cosmopolitismo que carece del prestigio que pudo tener en el pasado. Las aventuras y desventuras actuales del latinoamericano en la "ciudad luz" son más prosaicas que las de La Maga y Oliveira en Rayuela de Julio Cortázar y mucho menos rumbosas que las de Rubén Darío en el apogeo del Modernismo.

Pese a todo, la "ciudad luz" marca de un modo indeleble a escritores como el colombiano Pablo Montoya. Cuaderno de París (2006) es un canto nostálgico a la ciudad por la que deambuló en años que evidentemente fueron felices. Un errar sin destino fijo en el que se notan las marcas del spleen, del flanneur baudeleriano. Textos breves, fragmentos poéticos, apuntes sobre rincones, puentes, supermercados, avenidas, estaciones de metro, el cementerio Pere Lachaise que gracias al mapa de sus tumbas ilustres deja de ser "un lugar insípido", componen una sinfonía sobre una ciudad "amada y horrible" que no es otra cosa que "el reflejo de algo que busco con minucia y jamás encuentro. Escurridiza siempre, París. Fruta podrida. Llena de semillas infinitas" (2006:106). Esa ciudad de "todos los deseos y el remordimiento" provoca un solo anhelo: "regurgitar esa criatura temblorosa y desvalida que se llama poema" (2006:100).

Lejos de la poesía, el pícaro proxeneta peruano, protagonista de $E l$ tartamudo (2002) de Abelardo Sánchez León, no sabe por qué viaja a París en 1974: "No sé a qué vengo... Ya veré. Nunca se sabe lo que pasará" (2002:168), se dice despreocupado, para descubrir que la morada ideal del trashumante es un cuarto de hotel o un cuartucho como la Laura de Futoransky. Vivir en un cuarto de hotel, someramente equipado como "un dormitorio vacío; una cama, un ropero y un espejo" y un baño al final del corredor, le "evita rendir cuentas a la gente. El cuarto de un hotel rompe con el pasado - se dice - no hay nada tuyo. No acumulas. Es un eterno presente" (2002:203). Por su parte, las chambres de bonne en las que se enclaustran árabes, españoles, portugueses latinoamericanos, "como si sus encierros fueran unos sollozos interminables en los largos fines de semana" procuran un refugio perfecto: "Allí duermen, comen, se masturban y se aburren" (2002:205).

Sin embargo, la novela más representativa de la inmigración en París es El síndrome de Ulises (2005) de Santiago Gamboa que recoge en su título el nombre del mal que padecen los inmigrantes en la soledad de un país desconocido, incubado en los ghettos y barriadas en donde se hacinan los ilegales o de aquellos que corren el riesgo de pasar a serlo. El París de 


\section{Fernando Ainsa}

Gamboa no es el luminoso de turistas y estudiantes y menos la "fiesta" de Hemingway o Fitzgerald y su época o la ligera y entretenida de Alfredo Bryce Echenique. Está más cerca del París desaforado y precario de Henry Miller o al de El buen salvaje una desoladora novela de otro colombiano, Eduardo Caballero Calderón (Premio Nadal, 1965). Con Gamboa estamos en la ciudad subterránea y gris de los emigrantes, no solo latinos, sino asiáticos y europeos del Este, de todos aquellos que habiendo perdido toda esperanza en su propio país arriesgan la ilegalidad. ${ }^{7}$

París provoca otros males. Aquejado de una progresiva deformación - una joroba en forma de espolón creciéndole entre los omoplatos- que le va afectando el estado de ánimo hasta transformarlo en un irritable psicópata, el protagonista de Wasabi (1994) de Alan Pauls, un escritor argentino en residencia en Saint-Nazaire, vive también su dolencia con el agravante de estar en el extranjero. Estados catatónicos de narcolepsia lo agobian en forma imprevista, mientras va comprobando que no puede escribir el libro al que se ha comprometido como becario. Matar al pintor que debe hacerle la portada se convierte en su absurda obsesión, como si con ello pudiera cancelar su obligación. Cuando Tellas, su frívola compañera, lo deja para irse a Londres, París se transforma en un escenario de alucinada pesadilla, con su dédalo de túneles y pasillos interminables en un Metro que se ha convertido en una trampa de la que no es posible evadirse

¿Cuántas veces perdí el rumbo en Châtelet-Les Halles? ¿Cuántas veces malentendí carteles luminosos, reboté contra molinetes insobornables, deslicé boletos esperanzados en ranuras equivocadas? (...) Una y otra vez, hasta rendirme, interrogué los mapas adheridos a las paredes, y los

\footnotetext{
${ }^{7}$ En el París muy concreto de las banlieues y en los sótanos de los restaurantes toman forma los personajes de la resignación, aquellos que no tienen tiempo de pensar en sus males porque otros más pobres, más enfermos, más desvalidos o en general más desamparados dependen de ellos. Están ahí Jung el triste, Susi la gran chef de platos enlatados con arvejas, Saskia la rumana, o el polaco Lazlo, protector, teórico del cuerpo caliente y cazador de patos del Sena. Son sabios en sus desgracias, saben hace mucho tiempo que hacer preguntas no resuelve nada, en cambio beber, el sacrosanto trago de los desposeídos, ayuda. El París de la superficie, el París-capitaldel-mundo emerge a ratos, en los destellos de Paula el hada madrina y musa libertina, en los consejos del grave Kadhim, en las apariciones de la tentadora Victoria, o en los fugaces Goytisolo y Ribeyro, especímenes de la Literatura de los consagrados en París, como pudo ser Julio Cortázar. Ulises no es ya el hombre aventurero de la ciudad que describe Joyce, es el ser humano que trata de tocar las puertas de los países desarrollados. Su nombre -Ulises- no es el de un viajero épico, sino el de una enfermedad diagnosticada con pesar en los hospitales del primer mundo.
} 
itinerarios luminosos que tracé, tecleando como un disléxico las botoneras, siempre ignoraron mi destino (1994:118). ${ }^{8}$

\section{"I AM AMERICAN..."}

No sólo Europa o la lejana China, sino también Estados Unidos, centran una narrativa que parece haber perdido sus referentes territoriales y propiciado mestizajes múltiples. El polo americano, donde residen muchos escritores y desde cuya perspectiva escriben, constituye uno de los ejemplos más palmarios de esta nueva cartografía alternativa que propone tanto la búsqueda del paraíso, como un descenso a los infiernos.

Si los hispanics de Estados Unidos se expresan con fuerza y originalidad desde Nueva York a San Francisco, pasando por Texas y Nuevo México - como ha demostrado la antología de Se habla español. Voces latinas en USA, donde se explora "lo que hay de ellos en nosotros, y de nosotros en ellos" y también "las diferencias entre nosotros" (Paz Soldán 2000)— otros escenifican directamente sus novelas en Estados Unidos como el chileno Ariel Dorfman (1942), autor de Terapia (2001), localizada en Filadelfia, y el propio Edmundo Paz Soldán en Los vivos y los muertos (2009).

Esta última novela Los vivos y los muertos ${ }^{9}$ es una eficaz y apasionante inmersión en la mediocre vida provinciana larvada por tensiones soterradas, donde los mundos virtuales de la informática — correos, chats, blogs, programas como YouTube, MySpace, Linaje, Facebook, Free Ones - alternan peligrosamente con la realidad y permiten identidades desdobladas y banalizar crímenes urdidos en la más profunda soledad. Mundo de gigantescos mall, con tiendas comerciales parecidas por las que se vaga ociosamente y restaurantes de franquicia que garantizan idéntico gusto en cualquier punto del país, donde circulan

\footnotetext{
${ }^{8}$ El desesperado escritor sube y baja escaleras mecánicas comprobando que más de la mitad están descompuestas, sigue a pasajeros pensando que van en su misma dirección y queda atrapado en un vagón detenido por una alerta a la bomba. París es una trampa, pero también el atisbo de una liberación. Cuando al fin se queda solo y comprende que vivir no es simplemente "poner un pie delante del otro" ni el resultado de "un ejercicio respiratorio, inhalar, expirar, el mínimo de aire necesario para que la sangre siga circulando por el cuerpo" (1994:131), descubre que la juventud es más extraña que la ficción, suerte de moraleja de ambiguo significado.

9 "Comencé a escuchar voces", confiesa el boliviano Paz Soldán en la nota final que explica la novela, inicialmente concebida como una investigación periodística sobre una serie de muertes violentas en Madison, una gris ciudad del Middle West norteamericano donde ya había escenificado parte de La materia del deseo (2001). Son las voces de sus habitantes: adolescentes, niños, mujeres frustradas y un veterano de la guerra del Golfo expulsado de las fuerzas armadas, que van contando en forma alternada y progresiva —al modo del coro familiar de As I lay dying de William Faulkner- sus obsesiones y pequeñas ambiciones. El autor puntualiza que en principio poco tenía en común con esas "voces" tan ajenas a su propio mundo, pero las hizo suyas y las convirtió en "un relato muy personal".
} 


\section{Fernando Ainsa}

desarraigadas tribus urbanas con sus códigos de comportamiento y vestimenta (poleras de determinadas marcas, vaqueros de corte elegido según la pertenencia del grupo) son el escenario en el que un desorientado grupo de jóvenes, ${ }^{10}$ la mayoría universitarios, comparten el desarraigo y el aburrimiento y una extraña vocación por el suicidio o el crimen. ${ }^{11}$

Hay otras variantes en una narrativa escrita desde y sobre Estados Unidos por la diáspora o por hijos de emigrantes: la de escribir sobre la experiencia norteamericana de personajes latinoamericanos. Hijo de madre guatemalteca y padre judío americano, nacido en Boston, Francisco Goldman es autor de El esposo divino (2004) una novela sobre la vida de José Martí en Nueva York y la misteriosa relación con la joven guatemalteca que le inspiró el famoso poema de "La niña de Guatemala".

En una época muy solitaria y "extraña" de su vida — según él mismo ha reconocido- Goldman se empapó de la figura de Martí, llegando a leer parte de las más de 3.000 páginas que dejó escritas, preguntándose, en primer lugar, quién era en realidad este hombre. Martí le interesó como un hombre lleno de dudas, virtudes y defectos, más allá de la "gruesa capa de mentiras que oscilan entre la hagiografía y el sentimentalismo" (...). La ficción, en tanto que instrumento "ágil y elástico" le ofreció la posibilidad de subvertir la versión oficial y restaurar, en la medida de lo posible, la verdad oculta de ese personaje

\footnotetext{
${ }^{10}$ Jóvenes que pasan horas en los gimnasios modelando cuerpos cuyos paradigmas son los musculosos seres pixelados de la pantalla del computer, como Jem; adolescentes entregadas al culto de ser cheerleaders, como Hannah, o pendientes de relaciones amorosas, muchas veces reducidas a un blow job en el asiento trasero de un automóvil (Yandira y Hannah) o un hand job frente a la pantalla; mujeres maltratadas resignadas a ser objeto de prácticas sadomasoquistas, como la "señora Web"; niños que prolongan en el mundo la violencia de los juegos de una play station (Junior y Tommy), entrecruzan sus destinos en una verdadera saga construida como un puzzle que va combinando fatalmente sus piezas. Seres traumados por la guerra del Golfo — como Webb- familiarizados con la muerte que han vivido como algo cotidiano, y refugiados ahora en los blogs de suicidas y asesinos, la pornografía de la red y la sórdida prostitución de tugurios suburbanos, urden una violación y terminan cometiendo un doble crimen horrendo. En este contexto, no es extraño que el violador y asesino que desencadena una tragedia parezca un ser normal, uno de esos hombres frustrados entre los cuarenta y cincuenta, atrapado en un matrimonio infeliz, sin trabajo y sintiendo las primeras punzadas de que la época de la inmortalidad había quedado atrás y ahora, en cualquier momento, podía llegar el fin. Asustaba más pensar que era un ser normal (2009:133).

${ }^{11}$ Sobre este juego de máscaras virtuales y reales, el cielo opresivo de la ciudad de Madison sólo parece "perfecto para los funerales amargos en cementerios con lápidas semienterradas en la nieve" (2009:129) algo que parece confirmar la reflexión inicial: "Algún día todos los que en este momento están vivos en Madison estarán muertos" (2009:39). De la violencia y la muerte que la proliferación de armas favorecen, es difícil escapar. Al final se trata, simple y metafóricamente, de "salir con vida de Madison". Sólo Amanda lo logra, con la promesa y la fuerza que da la escritura y el propósito de "escribir sobre los vivos y los muertos", novela que muy probablemente Paz Soldán ha hecho suya.
} 
joven, guapo y seductor, fascinante mezcla de "poeta, soñador, periodista sin par, y gran prosista", que pasa en Guatemala dieciocho meses para exiliarse luego por dieciséis años en Nueva York. De ahí surge El esposo divino, plena del misterio que envuelve el amor con la "niña de Guatemala" y la vibrante vida neoyorquina que Martí tan bien reflejó en sus crónicas periodísticas.

Los ejemplos de integración de la diferencia abundan. Oscar Hijuelos en Nuestra casa del fin del mundo (1983) narra la historia de una familia cubana que llega a Estados Unidos en la década del cuarenta y en Los reyes del mambo tocan canciones de amor (1990) la de dos hermanos que viajan desde La Habana a Nueva York para tocar en los clubes latinos como los de Tito Puentes y Celia Cruz. Novelas de una historia tan cubana como norteamericana, alejada de problemas identitarios y saludadas por la crítica como parte de un patrimonio común, no necesariamente signado por el exotismo o la marginalidad.

El peruano Daniel Alarcón, radicado desde pequeño en Estados Unidos, escribe en inglés Radio Ciudad Perdida (2007), novela sobre una sociedad traumada por una guerra civil en un país latinoamericano no identificado, donde la protagonista, Norma, conductora de un programa radial - "Radio Ciudad Perdida, un espacio para gente desaparecida" - intenta reunir familias que han sido dispersadas por el conflicto. La idea es simple y exitosa. “¿Cuántos refugiados habían llegado a la ciudad? ¿Cuántos de ellos habían perdido contacto con sus familias? ¿Cientos de miles? ¿Millones? Para la emisora era una forma sencilla de aprovecharse de su angustia. Y para Norma la forma más efectiva de buscar a su esposo" (2007:21).

Alarcón no hace concesiones. Su temática, ceñida a un mundo donde impera la violencia y se reconocen posibles escenarios continentales (¿El Salvador, Guatemala, Colombia, Perú?) está escrita en inglés. A diferencia de otros narradores que al escribir en inglés lo hacen sobre un escenario norteamericano, aunque sea para referirse a problemas de exilio, identidad, inserción o desarraigo, Radio Ciudad Perdida anuncia una variante literaria de insospechadas perspectivas: temas latinoamericanos escritos en inglés, lo que en el pasado sólo parecía privilegio de escritores nacidos fuera de fronteras. Basta pensar en la obra W.D. Hudson.

El dominicano Junot Díaz (1968), autor de Drown (1996) gana en 2007 el prestigioso Premio Pullitzer con La maravillosa vida breve de Oscar Wao (2007), donde aborda la dictadura de Trujillo como una expresión del "mundo secundario" al que define como "ese espacio donde se pueden reordenar los elementos del mundo real de manera totalmente novedosa" recuperando la capacidad de asombro privativa de la niñez. Su inserción es total. Sin embargo, ante la pregunta de un periodista: “ ¿Cree que en Estados Unidos hay miedo al avance del español?", responde con tono entre serio y bromista 


\title{
Fernando Ainsa
}

\begin{abstract}
¿Por qué cree usted que combaten el bilingüismo, que en el resto del mundo es una bendición? ¿Por qué cree usted que apenas traducen a los autores que escriben en español? El mercado está ahí, los lectores están ahí y todo el mundo se cruza de brazos. EE.UU. es la zona cero de la lucha entre el inglés y el español, y lo saben. El miedo que tienen es inconsciente, pero muy real. A veces a la gente se le pregunta en qué idioma sueña. $\mathrm{Si}$ a los americanos alguien les preguntara en qué idioma tienen pesadillas no hace falta esperar a que contesten. Las tienen en español (2008:36).
\end{abstract}

Díaz va más lejos: "la literatura de calidad escrita por los latinos en Estados Unidos ya forma parte de la literatura norteamericana". Por lo tanto, recomienda integrarse sin complejos a la literatura del país en que se vive.

Otros escritores, como Xavier Velasco van y vienen entre mundos en apariencia antagónicos: México y Estados Unidos. En Diablo Guardián (Premio Alfaguara, 2003) construye con tono desaforado y un lenguaje popular avasallante, el personaje femenino de Rosalba que a los quince años y tras robar a sus padres el producto de una estafa a la Cruz Roja de "ciento catorce mil seiscientos noventa dólares", se escapa a Estados Unidos y lleva una vida desenfrenada hasta agotar el peculio. Luego se prostituye y sobrevive malamente como indocumentada. En Nueva York se deja corromper por la ciudad en la que "de cualquier manera iba a vivir" y se dice "me siento oscura y luminosa, provinciana y newyorka, violada y violadora; traigo un motor adentro y me dan muchas ganas de usarlo para estrellarme contra una pared" (2003:182).

Rosalba se repite "soy gringa" y "I' m american", siguiendo el ejemplo de sus padres que se tiñen de rubio y hablan entre ellos en inglés, no puede disimular su origen e intenta convertirse en Violetta R. Schmidt, "mexicana en New York, hija de padre alemán y madre canadiense" (2003:230), la heroína del "cuento" que se ha contado a sí misma. Consciente de ser una "güerita renegada", una "gringa de caricatura", Violetta se acusa de "ser yo por todas partes. O sea de querer siempre ser otra. Y hasta peor: conseguirlo" (2003:11), aunque se diga “¿Quién soy para saber quién soy yo?” (2003:87). Finalmente descubrirá que si se escapó de su casa buscando libertad, en realidad lo ha hecho para criar sus propias esclavitudes. "Esclavitudes diseñadas a la medida de ambiciones un poquitito menos estúpidas" (2003:357), que conducen a la comprobación final: "Esta vida es un Gulag" $(2003: 428){ }^{12}$

\footnotetext{
${ }^{12}$ La picaresca de los indocumentados para sobrevivir en un hostil Estados Unidos, culminado en un fracasado regreso a un México no menos cruel, alterna en una doble visión de mundos confrontados que, finalmente, resultan ser complementarios, incluso en el lenguaje. Velasco alterna el lenguaje coloquial mexicano y sus pirotécnicas ocurrencias con populares expresiones en inglés. Lejos de los tópicos del género, Diablo Guardián apuesta por una ambivalente coexistencia. Ambivalencia y contradicción de sentimientos que el colombiano Jorge Franco
} 
Palabras nómadas: los nuevos centros de la periferia

\section{HUIR HACIA UNA REMOTA PERIFERIA}

Se trata - para otros - de huir hacia los márgenes, a una remota periferia, vivir la liminaridad, instalarse en los confines donde llevar a cabo una experiencia de aprendizaje y subjetividad. Decía Marguerite Yourcenar que el emperador Adriano amaba los confines - los limes o límites del imperio romano- porque le conferían libertad. Le brindaban, también, extrañeza y le propiciaban una quimérica fertilidad intercultural que aprovechó a su pesar el desterrado Ovidio (Yourcenar, 2005).

En Lejos de Roma (2009), Pablo Montoya se instala en esa periferia y lo hace asumiendo los riesgos de abordar un tema trillado por los escritores: el destierro de Ovidio en los confines del imperio romano, Tomis, hoy la ciudad de Costanza o orillas del mar Negro en Rumania, donde vivió los últimos años de su vida sin poder regresar nunca a Roma. ${ }^{13}$

Montoya sucumbe, también, a esa tentación y conociendo su vida es posible preguntarse si detrás de Lejos de Roma, no hay un alusivo "Lejos de París". Si Pablo habla por boca del triste Ovidio con nostalgia de un centro evocado desde la periferia, su reflexión está empapada de erudición, poesía, reflexiones sobre un entorno que lo va apresando, pese a su elitista displicencia inicial. "En París me pregunté si era recomendable detenerme en las vivencias de los desterrados y refugiados políticos que uno encuentra en todas partes, pues muchas obras tocan ese tema, desde el "boom" latinoamericano hasta $E l$ síndrome de Ulises de Santiago Gamboa", ha explicado el propio Montoya. Lejos de Roma ofrece un Ovidio muy personal, que llega a ser íntimo. Aunque ha leído mucho sobre Ovidio su novela está concebida en un "aquí y ahora"

plantea y no intenta resolver. Aunque su madre le aconseja “¡no salgas a la calle!”, Marlon Cruz — el protagonista de Paraíso travel (2001) — guiado por "ese amor pesimista que siempre le ha tenido a la vida", se lanza tras Reina en su disparatada "búsqueda de futuro" en Nueva York. Se trata de huir del "mierdero" local para evitar estar "jodidos" como todo el mundo. Las triquiñuelas para poder entrar en Estados Unidos, billetes de avión de ida y vuelta a Guatemala, ropa de color negro para cruzar clandestinamente de noche la frontera con Estados Unidos, son capítulos de la saga de un inmigrante ilegal perdido finalmente en la ciudad desconocida y hostil tras una esquina que parece idéntica a la otra. Paraíso travel no es otra que la crónica de una jadeante búsqueda del amor extraviado en esa esquina: "hasta la meta, hasta donde acaba la búsqueda o donde la película dice fin, hasta donde terminan la fatiga y el cansancio" (2001:33). Convencido de que el regreso a Colombia es imposible, ya que "nadie vuelve para olvidar", asume con resignación "el dolor y la incertidumbre de ser colombiano" y comprende que no se puede cambiar de patria, porque "la patria es cualquier lugar donde está el afecto" (2001:242).

${ }^{13}$ El exilio del autor de Tristes, las cinco elegías que escribió atenazado por la nostalgia, es una figura literariamente tentadora y así lo han entendido los escritores que la han novelizado, especialmente el austriaco Christoph Ransmayr, autor de El último de los mundos y a quienes la aluden en sus obras como Claudio Magris y la propia Yourcenar. 


\section{Fernando Ainsa}

en el que se reconoce sin dificultad el lector. Ovidio, sin perder sus rasgos ni su condición de romano, es un exiliado moderno.

Con todas las licencias que da la literatura, el poeta Ovidio de Montoya ha leído a Borges, Kafka, Ciorán y a Bolaño. También ha conocido a desplazados y presos políticos, y sabe cómo se atenta contra la libertad. "No sé si mi obra acerca al lector al Ovidio histórico, o lo lleva a hacer una serie de consideraciones sobre el exilio de los escritores". Después de leer Lejos de Roma sospechamos que logró las dos cosas.

Con un estilo tan elegante como moroso, a través de capítulos breves, en Lejos de Roma vamos descubriendo que el rechazo inicial a ese vivir en el último "confín del mundo" — a esa "relegación" por el implacable emperador Augusto sentida dolorosamente en carne propia, a esa imposibilidad de concretar la palabra "vuelve" pronunciada en la soledad del silencio nocturnose va transformando en un resignado disfrutar del retiro y en reflexionar sobre la relativa condición del exilio.

No es fácil hablar del exilio cuando estamos en un supuesto centro - se afirma- Quienes deberían hacerlo serían aquéllos que como tú padecen las contingencias de la marginación. Sé muy bien que frente al tema de la expulsión de los hombres de sus tierras se cae en el terreno de la relatividad. No existe un único centro en los reinos del universo. El centro está en todas partes siempre y cuando haya un hombre sensato habitándolo (...) Roma y todo centro erigido por los hombres, no es más que una ilusión.

En Cuaderno de París Montoya ya había confesado estar "aturdido de tanta diáspora y coordenada", creyendo "vano procurarme un centro". Pero hay un remedio para superar ese "descentramiento" y Lejos de Roma nos lo propone: el mejor lugar para comprender la fisura del que no se siente de ninguna parte es sumergirse en los libros, sobre todo en aquellos que intentan "trazar el paso de los hombres en la tierra, ese trasegar intermitente en busca de una felicidad que no existe". Séneca desde el otro confín del imperio romano, en la docta Córdoba, proponía: "Hay que vivir con esta persuasión: no hemos nacido para un solo rincón. Nuestra patria es todo el mundo visible".

Moraleja, si pudiera haberla: sospechar con desdén de los hombres que se creen superiores porque han vivido más intensamente el desarraigo, aunque paradójicamente, es en el exilio donde se llega por fin a ser un hombre. Lo había propuesto como una metáfora poética el propio Montoya en Viajeros

En el exilio la nostalgia nos ilumina y nos consume. En el exilio un diálogo persistente con nuestra sombra quieta. En el exilio el primer y el último crepúsculo reflejan el aparente paso de los días. En el exilio el eco de los hallazgos se difumina y su opacidad es inmensa. En el exilio 
la tierra acosa en su ineluctable distancia. En el exilio tu fuga, amor, es definitiva.

Pablo Montoya, tal vez sin saberlo, tras errancias varias, con ese dejo de spleen baudeleriano que lo caracteriza, ha ingresado con Lejos de Roma en la madurez literaria: la que da el sosiego de una lectura clásica de los clásicos.

Ahora parecen descubrirse las potencialidades, la fertilidad de la distancia - como hace Luis Sepúlveda siguiendo las huellas de Coloane en Tierra del Fuego o de Bruce Chatwin en la Patagonia- aunque la connotación metafórica del confín como periferia extrema le otorga una imprecisa y movediza delimitación. No se trata, en todo caso, de formas paroxísticas de la huida como la de Arthur Rimbaud en Abisinia o Arturo Cova, el protagonista de La vorágine de Rivera, hacia el corazón de la selva colombiana, sino de una especie de viaje fundacional al modo de Horacio Quiroga en las Misiones. La auténtica patria literaria está, tal vez, ahí: en el confín, en una periferia a la que se le ha descubierto un centro o que se lo busca a través de una errancia en apariencia sin rumbo. "Los confines mueren y resurgen, se detienen, se cancelan y reaparecen inesperadamente" recuerda Claudio Magris (1991:38) cuya sinuosa y sugerente lejanía elabora los mapas de la geografía alternativa de las pertenencias.

En la mejor tradición de On the road (1957) de Jack Kerouac que consagró el género novelesco de la vida en las carreteras, Osvaldo Soriano en Una sombra ya pronto serás (1990) se lanza con humor al vagabundaje itinerante y sin sentido aparente, al modo de los road movies del cine norteamericano, para proponer una parodia de novela de viaje e iniciación con un protagonista "cansado de llevarse puesto", aunque el recorrido absurdo por el mapa de una monótona geografía pampeana lo devuelva a su punto de partida o a otro idéntico. Las aventuras encadenadas de una galería de personajes tan exóticos como marginales - un acróbata prestidigitador, una astróloga, un banquero desaforado, dos jóvenes que quieren irse en un destartalado Mercury del 47 hasta los Estados Unidos - perdidos en la inmensidad de una Argentina vacía, con rutas imposibles y pueblos de calles vacías, donde el camino es el protagonista y los personajes simples mojones que van marcando el errático itinerario. "Ahora no sabía adónde iba pero al menos quería entender mi manera de viajar", se dice el protagonista frente a un camino donde todo es igual a otros caminos: alambrados, vacas, alguno que otro árbol. La buscada evasión a través del moverse en permanencia es inútil, porque una moraleja secreta se esconde en la interrogante: “¿Por qué si una vez conseguí salir del pozo volví a caer como un estúpido?". "Porque es tu pozo" - se responde- porque lo cavaste con tus propias manos" (1990:14).

No hay tampoco reposo en la búsqueda que se encadena alegóricamente en Crónica del gato que huye (1996) del uruguayo Hugo Burel. A partir de la respuesta de Bruno Leal —un "exiliado económico en la Reina del Plata" 


\section{Fernando Ainsa}

cuya lucha por la supervivencia ha "clausurado la nostalgia"- a un impreciso anuncio ofreciendo un empleo en la Compañía Manufacturera del Sur, una empresa de la que se ignora a qué se dedica, se inicia una desconcertante búsqueda en tierras tan áridas como despobladas de la pampa argentina. Citas en pueblos destartalados, hoteles fantasmales, un viaje en un anacrónico Packard por una carretera plana y monótona recta como "un tajo sobre la planicie verde y reseca", suerte de "pesadilla geográfica" alrededor de Linares - una ciudad en decadencia - un limbo en el medio de la nada. Sin saber en qué consiste su trabajo, desconcertado por variados y contradictorios interlocutores, Leal, "como un peregrino que se ha extraviado en el camino de Santiago" (1996:116) llega a sentir que la fe es "una palabra sin sentido, un desvarío producto del calor" (1996:121). Los caminos son circulares, hay desvíos y rutas clausuradas, los viejos y arrugados mapas pierden su objeto y una fuga alucinada en una pick-up conducida a gran velocidad desemboca en un pueblo abandonado para regresar a Linares sin quererlo

Detenido en un tiempo que más que transcurrir era capaz de bifurcarse, repetirse y regresar, instalándose como una melaza invisible entre los hombres y las cosas, inundando toda la humilde geografía circundante hasta detener el decurso lógico de los instantes, agolpándolos en una simultaneidad inútil (1996:155).

Cuando Leal descubre que la Compañía Manufacturera se ha reciclado en una realidad virtual - Irondrag — que puede visitarse al modo de la isla de La invención de Morel de Bioy Casares, todo parece cobrar el sentido de una gigantesca estafa perpetrada para beneficio de unos inescrupulosos que han corrompido toda la región. Sin embargo, prisionero de la lógica diabólica que lo ha llevado a "errar por caminos polvorientos, conociendo gente violenta, cínica o simplemente equivocada, durmiendo mal y comiendo peor, gastando el dinero en pensiones miserables o en viajes inútiles" (1996:198), Bruno Leal decide pasar del sueño virtual a una realidad de carreteras interminables y precarios hoteluchos, convirtiéndose en viajante que recorrerá ese paisaje desolado para siempre. Por eso se dice en las líneas finales que "los signos extraordinarios ya han cesado y el porvenir es largo, como este camino que me va llevando al sur lejano" (1996:207).

\section{LOS NUEVOS CENTROS DE LA PERIFERIA}

Una primera comprobación se impone: el canon actual de la literatura latinoamericana está disperso. Ha perdido sus tradicionales referentes nacionales. Frente al fenómeno de escritores latinoamericanos acusados en el pasado de ser desarraigados, rastacueros, trasplantados - tal como se calificaba a fines del siglo XIX y principios del XX a quienes habían "hecho sus maletas", al decir de Flaubert- lo que resulta ahora novedoso es la nueva aculturación creada. 
Lejos del debate de los años sesenta entre los escritores de "adentro" y de "afuera" — del que la polémica entre José María Arguedas y Julio Cortázar fuera su ejemplo paradigmático - se comprueba que es posible participar en las otrora prestigiosas capitales de la cultura aportando una visión periférica y marginal generadora de nuevos y dinámicos centros.

Podríamos hablar así de un "nomadismo fundador", por no calificarlo simplemente de una nueva invasión de los "bárbaros". Desde esta perspectiva la literatura latinoamericana ya no se percibe como una manifestación valiosa de "una región en vías de desarrollo" que merece ingresar con un capítulo propio en la literatura occidental — como se reclamaba en los años sesenta, en el apogeo del boom - sino como parte del pluralismo multipolar a través del cual se expresa el mundo contemporáneo, esos centros provenientes de la periferia que se instalan en los centros imperiales de antaño.

La paradójica consecuencia es que a través del "complejo universalismo" (Picón Salas, 1969:65) y del "universalismo enraizado" (Reyes, Alfonso) se afianza mejor la diversidad. El mundo es un espejo donde se reflejan todas las expresiones nacionales, enviándose mutuamente imágenes y destellos. Valores estéticos, constantes temáticas, similares inquietudes reaparecen en diferentes latitudes gracias al poder de la comunicación y la simultaneidad. Este reflejo del fragmento en el todo, da la ilusión de una contemporaneidad donde ha desaparecido la bipolaridad patria-afuera.

Sin embargo, la norma es lo excéntrico, la centralidad de lo excéntrico, la falsa periferia del sistema, lo que divierte a Damián Tabarovsky (1967), autor de La expectativa, Autobiografía médica: "Esta otra literatura, la más radical, la más desafiante, ocupa una posición cada vez más central en el mercado". Por ello, se pregunta "¿Se puede ser excéntrico y central a la vez?" Con ironía, Héctor Libertella proclamaba: "Si Argentina es un país periférico en el mundo, su escritor más periférico será entonces centralmente argentino. A mí me ha costado mucho sostener esta paradoja... ¡Cuanto más marginal, más central".

Res.: Apartado postal 10316*

50006 Zaragoza (España)

fernandoainsal@gmail.com 
Fernando Ainsa

\section{BIBLIOGRAFÍA}

ABELLÁN, José Luis. Ideas para el siglo XXI. Madrid: Libertarias, 1994.

ALARCÓN, Daniel. Radio Ciudad Perdida. Madrid: Alfaguara, 2007.

ARIAS, Arturo. Sopa de caracol. Guatemala: Alfaguara, 2002.

BUREL, Hugo. Crónica del gato que huye. Montevideo: Fin de siglo, 1996.

DÍAZ, Junot. El País. Madrid: 1 mayo, 2008.

DITTBORN, Eugenio. "Entrevista aeropostal" con Sean Subitt, en Art from Latin America. (Ed.) Nelly Richard, Sydney, Museum of Contemporary Art, 1993.

FLAUBERT, Gustave. La religión del arte. Buenos Aires: Elevación, 1947.

FRANCO, Jorge. Paraiso travel. Bogotá: Seix-Barral, 2001.

FUTORANSKY, Luisa. Son cuentos chinos. Madrid: Albatros, 1983.

----- De Pe a Pa (o de Pekín a París). Barcelona: Anagrama, 1986.

GARCÍA AGUILAR, Eduardo. "Licuadora, diásporas, éxodos, globos", en Palabra nómada. París: Vericuetos 20:2006.

HEIDEGGER, Martin. Caminos de Bosque. Madrid: Alianza. 2001.

JOYCE, James. A portrait of the artist as a young man. New York: Viking Press, 1956.

MAFFESOLI, Michael. El nomadismo. Vagabundeos iniciáticos. México: Breviarios F.C.E., 2005.

MAGRIS, Claudio. El Danubio. "Come il pesce il mare", en Frontiere, Nuovi Argomenti. 1991:38.

MALLEA, Eduardo. Historia de una pasión argentina. Buenos Aires: Losada, 1939.

MONTERROSO, Augusto. "Dejar de ser mono", en Movimiento perpetuo. Madrid: Biblioteca El Mundo, 2001.

MONTOYA, Pablo. Cuaderno de París. Medellín: Fondo Universidad, 2006.

PAZ, Octavio. El laberinto de la soledad. México: F.C.E., 1982.

PAZ SOLDÁN, Edmundo; FUGUET, Alberto. Se habla español. Voces latinas en USA. Miami: Alfaguara. 2000.

PAZ SOLDÁN, Edmundo. Los vivos y los muertos. Madrid: Alfaguara, 2009.

PICÓN SALAS, Mariano. De la conquista a la independencia: tres siglos de historia cultural hispanoamericana. México: F.C.E., 1969.

RIBEYRO, Julio Ramón. Prosas apátridas. Barcelona: Tusquets, 1975.

SÁNCHEZ León. Abelardo: El tartamudo. Lima: Alfaguara, 2002.

STEINER, George. Extraterritorial. Barcelona: Barral, 1973.

VÁSCONEZ, Javier. El viajero de Praga. México: Alfaguara, 1996.

VÁSQUEZ, Juan Gabriel. "Guerra contra el cliché”, en Babelia: El País, 24/11/07.

VELASCO, Xavier. Diablo Guardián. Madrid: Alfaguara, 2003.

VILA-MATAS, Enrique. Vila-Matas portátil: un escritor ante la crítica. Barcelona: Candaya, 2007.

VOLPI, Jorge. "Perder los papeles", en El País. Madrid: 27 junio, 2008.

YOURCENAR, Marguerite. Memorias de Adriano. Barcelona: Quinteto, 2005.

WHITE, Kenneth. El testamento de Ovidio. Bolonia: Il Pomerio, 1997. 